\title{
Decision Making in the Southern African Development Community
}

\author{
Sibusiso Moyo (Corresponding Author) \\ Department of Political and Administrative Studies, University of Zimbabwe \\ P O Box MP161, Mount Pleasant, Harare, Zimbabwe
}

Tel: 263-4252-036Ｅ-mail: sbmoyo@rocketmail.com

Charity Manyeruke

Faculty of Social Studies, University of Zimbabwe

P O Box MP 161, Mount Pleasant, Harare, Zimbabwe

E-mail: nevanjicm@gmail.com

Received: March 17, 2015 Accepted: April 16, 2015 Published: April 27, 2015

doi:10.5296/jsss.v2i2.7262ＵRL: http://dx.doi.org/10.5296/jsss.v2i2.7262

\begin{abstract}
As signatories to the Southern African Development Community (SADC) Treaty, member states agree on certain principles and objectives which guide them and the security community in decision making. To this end, the SADC through its founding document, the SADC Treaty, sets out the technical details about decision making processes in the organisation. The purpose of this article however, is to analyse what other factors impact upon and influence decision making in the SADC. Findings of the study indicated that member states at times make decisions which undermine the effectiveness and principles of the SADC Treaty. The study was based on a qualitative methodology which made use of documentary search and content analysis. Some states were found to make decisions based upon patron-client relations and prioritisation of national interests over regional interests. Apart from actions taken by some member states, the study also identifies funding and external influences as factors which impact on the SADC's decisions and undermine the values and principles of the SADC Treaty. The role of personalities in enforcing the values of the SADC Treaty was also identified as a factor in the organisations decision making. The study recommends that the SADC member states make their decisions with their regional
\end{abstract}


commitments as a priority and in the framework of the SADC security community ideals.

Keywords: SADC, SADC Treaty, decision making, security community

\section{Introduction}

The SADC is a regional security community which was founded in 1992. Deutsch (1953:91) defines a security community as "a group with shared identities, values, and meanings, with complex sustained interpersonal encounters." When states can identify with one another and interact at this level, they form a community. Whilst they have an individual identity, they also share a common identity which they seek to preserve, protect and enhance. When this happens, a security community is conceived. The SADC's objectives are contained in Article 5 of the SADC Treaty which guides the decision making processes and within whose spirit the SADC as a security community as well as individual member states make their decisions. These objectives are inclusive of promoting and defending peace and security; evolve common political values, systems and institutions; achieve complementarity between national and regional strategies and programmes and promote self-sustaining development on the basis of collective self-reliance.

The foregoing objectives are guided by the principles contained in Article 4 of the SADC Treaty and they are inclusive of sovereign equality of states; solidarity, peace and security, equity, balance and mutual benefit. The SADC Treaty denotes a collective identity and common objectives, values, norms which are achievable through collective action and interaction at various levels. Adler (1998:265) notes:

shared self-definitions create internalised norms that allow people from different countries to know each other better and thus respond more effectively to common concerns. Social learning, especially coupled with positive functional processes, contributes to the emergence of security communities, as states tend to behave according to norms that shared values and identities have constituted.

These characteristics are also meant to apply to the SADC as a security community. The ideal assumption which follows Deutsch and Adler's perception of a security community is that decision making in the SADC is relatively simplified because member states have a unity of purpose, a unity of mind. The shared values and identity is meant to provide an even platform from which SADC member states base decisions. This leads Ngoma (http://www.issafrica.org/uploads/PROSPECTSCHAP1.PDF), to observe that Deutsch regarded a security community as groups of countries, which "consist of people who have learned to communicate with each other and to understand each other well beyond the mere interchange of goods and services". Decision making in security communities is therefore enhanced by effective communication drawn from a deeper understanding amoung member states.

In addition to the shared vision entailed in a security community, decision making in SADC is also meant to be made less complex by the fact that in a security community, the rationale is to achieve collective action and coordination which achieves more than individual state's pursuit of national interest (Beyer, 2005:1). In this respect, the SADC member states have to subdue themselves to the supranational body and be bound by the body, thus providing a certain degree of predictability in the SADC's decisions. That is to say, the SADC Treaty and 
Protocols, additional protocols and Pacts outline how SADC ought to respond to various defence and security issues and the principles the organisation should base its decisions on.

The characteristics described above of a security community are an ideal. The reality in the SADC has at times been contrary. The following are a few examples in the experiences of the SADC, in which member states decisions have compromised the effectiveness of the security community in achieving its objectives. Unless the SADC member states make a concerted effort to abide by the principles and values of the SADC Treaty and make decisions with regional implications in mind, then the SADC will not achieve its maximum potential.

\section{SADC and United States Africa Command}

The position of SADC as a security community and of SADC member states over the United States Africa Command (USAAFRICOM or AFRICOM) provides some insights on decision making in the organisation and by the SADC members. AFRICOM operations began in 2007 as a vehicle for military engagement to foster military cooperation between the United States of America and African states. AFRICOM inevitably projects and protects American interests on the continent. America identified Africa as a haven and breeding ground of international terrorism. This was partly because of the presence and activities of the Salafist Group for Preaching and Combat (GSPC) in Mali, al-Shaabab and al-Qaeda in Somalia and Boko Haram in Nigeria which all pose as a threat to American interests and foreign policy.

As a result, in 2006 US Secretary of Defence, Donald Rumsfeld launched the process of creating AFRICOM which was to be fully operational with an established headquarters by 2008. According to Burgess (2008), in February 2007, President George W. Bush and the Secretary of Defence Robert Gates approved Rumsfeld's initiative, including the directive to place AFRICOM headquarters on the African continent. With this approval, USA officials began the process of informing African leaders about AFRICOM and attempting to persuade them that the new command was in Africa's best interests and that it posed no threat to Africa. However, from a realist perspective, USA's attempt to preserve its national interests through a more pronounced military presence on the African continent posed a threat to African states national interests and was not readily embraced. In Southern Africa, AFRICOM was faced with stiff resistance from the SADC which denounced AFRICOM.

Arguably, one of the major considerations taken by the SADC when deciding on a position concerning AFRICOM was that of the colonial legacy. According to Kfir (www.idc.ac.il/publications/files/376.doc), there is a general distrust that Africans have towards the West and increasingly towards the United States. The continent's bitter colonial legacy has continued to shape African thinking, especially in the way the continent's leaders interact with the global community. Thus, the idea of placing a large American base in Africa is an anathema to many Africans as it evokes notions of neo-imperialism.

Perhaps it was such a way of thinking which led South African Defense Minister Mosiuoa Lekota (2007) in a SADC meeting to declare that "Africa has to avoid the presence of foreign forces on its soil, particularly if any influx of soldiers might affect relations between sister African countries." This was a view shared by Zambian president, Levy Mwanawasa, who claimed that "none of the fourteen states that make up SADC are interested in having a US base on their soil." In addition, Kfir (www.idc.ac.il/publications/files/376.doc), states that 
"Minister Lekota also issued a careful warning to those African countries that may consider hosting AFRICOM, by stating that such a move would undermine African solidarity. The warnings came after Liberian President; Ellen Johnson Sirleaf expressed support for the new command. Decision making in the SADC is therefore affected by historical experiences faced by the region and its guard against neo-imperialism in its various forms. This is so to the extent that even if some SADC leaders decide to support a new initiative they will need to contend with opposition from fellow SADC leaders.

SADC's condemnation of AFRICOM partly stems from the formers' commitment to the principle of nonalignment. The Non Aligned Movement (NAM), of which every SADC member state is a member, is a group of states which are not formally aligned with or against any major power bloc. Founded in 1961 with principles of mutual respect for each other's territorial integrity and sovereignty, mutual non-aggression, and mutual non-interference in domestic affairs, the movement rejected the control by any superpowers. Lekota (www.dtic.mil/cgi-bin/GetTRDoc?AD=ADA539969) states that in rejecting AFRICOM, "SADC states believed that any US involvement in Africa should be from a distance and not on the continent." In this respect, the SADC's decision on AFFRICOM was partly based on the members' affiliation to the NAM and the principles it stood by.

Patron- client relations have served to undermine the unity of the SADC. While most of the SADC members agreed on the organisations position concerning AFRICOM, Botswana took a less extreme position. Botswana enjoys strong bilateral relations with the USA. While this is not wrong, these relations have at times compromised the objectives of the SADC. For example, the decision by the Government of Botswana to allow the United States Government to construct facilities inside the Thebephatshwa air base, the hosting of joint military exercises such as Exercise Southern Accord in 2012 and Exercise Eastern Piper 12 (under Africa Command and Special Operations Command) in 2012, both hosted at Thebephatshwa air base in Botswana are indications to the SADC that America's military interests in the region are increasing alongside speculation that Botswana is a possible site for the hosting of an AFRICOM base.

It is important to remember that Botswana is a sovereign state and is free to engage whichever country of its choice. However, she should be mindful of her actions impact on the SADC. It is the extent of relations between Botswana and the United States of America that has led the former to be branded as an American client-state in the SADC region with proxy American assets. The collective implementation of decisions taken by the SADC as a collective or as SADC members of the African Union has therefore been compromised by issues to do with patron client relations. This has the effect of undermining decisions and fragmenting the regional security community instead of integrating it.

Further elements of patron-client relations were revealed through leaked diplomatic cables (wikileaks) that stated in 2008 Botswana invited the USA to send troops to guard a transmission station used by the Voice of America's Studio 7 to broadcast into Zimbabwe. An online newspaper, www.newzimbabwe.com reports that this was because Botswana was concerned by the rising rhetoric against the radio station and feared that Zimbabwe would try and take out the transmitters. The station is funded by the United States Government. The report quotes Phillip R. Drouin, the Charge d'Affaires at the US embassy in Botswana at the 
time as saying that Botswana's invitation of US troops to be stationed on its soil provided "extensive background on President Khama's strategic thinking, decision making style, his views of and inclinations towards the United States."

Botswana's pro-West policy which has facilitated the hosting of what Zimbabwe calls pirate radio stations broadcasting illegally in Zimbabwe from Botswana has strained relations between the two SADC members. Botswana's decision to host and protect radio stations which broadcast illegally into Zimbabwe threatened the effective implementation of Zimbabwe's, SADC backed Global Political Agreement (GPA) which sought to reconcile competing political parties in the country. Article XIX of the GPA raised concern on foreign government funded external radio stations broadcasting into Zimbabwe which are against national interests and called for the hosting and funding of these stations to cease. Botswana's decision to neglect the security and interests of Zimbabwe were against the overall SADC objective but it was consistent with America's regime change agenda.

Botswana's approach to international relations has often been the cause of concern among SADC member states. A regional newspaper, Southern Times, carried an article entitled 'Khama risks SADC isolation' (24-30 August 2012). It highlights issues arising from a meeting between South Africa's ruling ANC party and Botswana's Botswana Democratic Party (BDP). It states that in spite of the ANC's respect of Botswana's President Ian Khama's right to speak on individual sovereign and international issues, it is important to maintain a collective position as SADC. The same article quotes the ANC's secretary general. Gwede Mantashe as stating that; there was disagreement on the handling of the Libya question...Botswana recognised the TNC (the Libya Transnational Council) before the African Union pronounced itself on the matter. The source of worry was that if member parties to the AU pronounce on issues before the AU, as a multilateral institution, it will weaken the $\mathrm{AU}$ in the face of other regional blocks.

Botswana also supported the no fly zone over Libya while the SADC was advocating for African solutions to African problems.

\section{Funding}

Another key factor which has undermined the effectiveness of the SADC decision making capacity is the issue of funding. The SADC is responsible for mobilizing finances necessary for the implementation of its programs. In addition, several International Cooperating Partners (ICPs) contribute substantially to the SADC budget. A key challenge that emerges for the regional security community is the difficult relationship that the regional body has with ICPs or donor countries. According to a 2006 report by the Botswana Institute for Development Policy Analysis, Foreign donors remain a crucial source of funding for SADC and its operations. External development finance and foreign donor agencies have played a critical role in the evolution of SADC, with the most prominent donors being the European Union, the Nordic countries, Finland, the UK, Germany and Switzerland (Tjonneland, 2006). Matos et al (2012:8) substantiates the need for external funding when he states that:

SADC as a whole displayed a Gross Domestic Product (GDP) of approximately 429.7 thousand million dollars in 2009. The population reached 276.4 million inhabitants in 2010. 
From that, 35.5 per cent live in urban areas, and the remaining 60.5 per cent are still in the rural areas. The GDP per capita was at around 1.555 dollars and the average Human Development Index was 0.381, way below the levels seen in developed countries. The area of SADC adds up to $9.854 \mathrm{~km} 2$, a territorial range greater than that of some countries like the United States, China and Brazil.

Prevailing financial constraints combined with the magnitude of the SADC mandate entail that the organisation accepts support for it to be functional and effective. While one of the primary reasons for the establishment of the SADC was to reduce economic dependence on apartheid South Africa, the organisation has relied heavily on donor financing. Malaebang (2012:51) states that "SADC member states insist on maintaining their autonomy especially in the area of foreign policy. Often donor countries tend to freeze aid to the regional body which is heavily dependent on donor funding and rather prefer to channel the aid to individual member states posing a threat to regional integration." Donor funding in the SADC therefore interferes with the organizations decision making process as it is not given the autonomy and discretion on the utilization of disbursed funds. Despite this interference, the SADC has no choice but to engage external funders, for example, following the 20 March 2013 Political Dialogue framework between the European Union (EU) and the Southern Africa Development Community (SADC) in Maputo, Mozambique, SADC secured funding to the tune of 20 million Euros from the EU. The funds were directed towards the Regional Economic Integration Support programme.

The source of SADC's funds, the amount of sourced funds and the financial capacity of the SADC member states all have an important bearing on the programmes and institutional designs of the SADC. Add to the fact that the SADC does not operate in a vacuum but in a global community comprising of other states and international organisations which may or may not share similar interests with the SADC and yet have a stronger financial capacity hence the issue of funding for SADC becomes more complex. External donors have built secretariat buildings, established institutions such as courts and parliaments, and supported various projects that often extend beyond the initial scope of the organization. External donors therefore have a considerable impact on SADC decisions.

In an article carried in one of Zimbabwe's local newspapers, The Zimbabwe Mail, (27 March 2014), Ncube quotes the country's Foreign Affairs Permanent Secretary, Joey Bimha as stating that External funding by the donor community is influencing decisions and projects being implemented by the Southern African Development Community, threatening its independency and sovereignty... Donors in the last financial year contributed $\$ 83$ million dollars while member states chipped in with $\$ 31 \mathrm{~m}$. As a way to protect the defense and security of the region and its member states, the SADC Organ for Politics, Defense and Security Cooperation is funded by contributions from member states and no donor funding is channeled towards the functions of the organ because it would want to maintain its independence and protect the interest and sovereignty of the member states from external interference.

De Carvalho, an Angolan economist (www.ascci.info) believes that the SADC has similar organs to the EU only that things unfortunately do not work, often because of matters of financing. He states that "The EU works with its own resources, member states make 
contributions, defined from the beginning and do not rely on donations. In the case of SADC, the contributions are actually defined, but there are states that delay their payment, which affects the effective functioning of the organisation, where each party wants to do things separately." The Herald (August 18, 2011) reports that in the SADC's 2011 budget, for example, only \$31 million was slated from member states; the remaining \$52 million came from external donors. Furthermore, that official figure for member contributions fell far short of the realized totals: only eight of the organization's 14 members actually paid their contributions, to a total sum of $\$ 5$ million.

Lenz (2012) states that international organizations do not frequently reflect the preferences or needs of member states per se, rather they are merely evidence of organizational adaptation in the face of budget constraints, and the institutions that they form are less representative of member-state concerns and more of the concerns of external actors. SADC has not been an exception, particularly encouraged and funded by the EU and other developing international cooperating partners; the SADC Tribunal was set up. According to Gray (2013:15) the case of SADC illustrates an example of an organization that was itself designed in part to attract and coordinate development aid, but when one donor initiative of institutionalization directly conflicted with member-state interest, it (the SADC Tribunal) was actively dismantled.

The SADC Tribunal was aimed at providing recourse and a legal remedy to disputes. However, it was supported by and partly funded by the EU and the fact that white commercial farmers from Zimbabwe approached it for relief did not help its credibility in the eyes of Zimbabwe. In 2007, a group of Zimbabwean white commercial farmers sought relief from the Tribunal over farms confiscated under the Governments Land Redistribution Programme and in particular under Constitutional Amendment 17 (also known as the Campbell case). This amendment essentially precluded jurisdiction of Zimbabwe courts in adjudicating cases of contested expropriation. The Tribunal accepted to hear the case based on the grounds that the farmers had no domestic remedy and could not proceed under the domestic jurisdiction. Nathan (2013:875), details the judgement of the Tribunal; The Tribunal ruled that the Zimbabwean Government was in breach of the Treaty because Amendment 17 violated two essential elements of the rule of law, namely the right of access to the courts and the right to a fair hearing before being deprived of right, interest, or legitimate expectation. It also stated that Amendment 17 targeted white farmers alone and did so regardless of other factors such as their citizenship, length of residence in Zimbabwe and proper use of their lands. The constitutional amendment thus amounted to indirect racial discrimination which was contrary to the Treaty and many international conventions.

A number of similar cases from Zimbabwe white commercial farmers were brought to the Tribunal following this ruling. The Government of Zimbabwe however did not agree with or enforce the Tribunals ruling, with the country's Justice Minister Chinamasa arguing that the Tribunal's judgement was not legally binding and that Zimbabwe would only submit to the ruling when the Tribunals constitution was ratified by at least two-thirds of SADC countries. In addition, the Minister stated that (http://www.southerntimesafrica.com/news_article) "unless SADC become financially independent it would be at the mercy of those with deep pockets." In Zimbabwe's perception therefore, the SADC Tribunal had ruled against it because it was forwarding the interests of its funders who were not supportive of Zimbabwe's 
Fast Land Redistribution Programme.

According to Gray (2013:10) the court continued to hear the additional cases, and "after making similar rulings in three similar ones, SADC halted the hearings while an independent review of the legality of the court was conducted, a review that was itself funded by an external actor, Germany." In 2010 the SADC Summit decided to suspend the SADC Tribunal. As the resolution stated, "Summit considered the Report of the Committee of Ministers of Justice/Attorneys General and the observations by the Council of Ministers and resolved that a new Protocol on the Tribunal should be negotiated and that its mandate should be confined to interpretation of the SADC Treaty and Protocols relating to disputes between Member States." The impartiality of the judiciary proved to be a challenge in the case of the SADC Tribunal. There is therefore a need for a higher degree of financial self-sufficiency if the $\mathrm{SADC}$ is to gain a credible amount of decision making autonomy.

\section{External Influence}

While external funding is a way in which the SADC's decision making capacity can be compromised, there are other less subtle modes of external interference. The SADC mediation in Zimbabwe provides evidence of the forces involved in decision making within the organisation. At times, external influences and pressures bear down on the organisation in order to alter or tailor an outcome favourable to interested third parties. The sovereignty and confidence of the SADC is severely undermined and compromised when the SADC has reached a decision and its implementation is interfered upon. Reference can also be made to the case of Malawi, which was threatened by withdrawal of donor support by the United States of America unless it supports gay rights. The point is decision making in the SADC is interfered with by external actors and against member states interests. Such was the situation in the case of Zimbabwe where there were conflicting expectations on the outcomes of the facilitation process. Chikane (2012:76) states that

For historical reasons, and in pursuit of their national interests, the United Kingdom and the United States of America took a direct interest in the development in Zimbabwe. They openly took sides with the opposition parties and some civil society groups against the ZANU-PF government, particularly its president and the president of the country, Robert Mugabe. The opposition to the ZANU-PF government and its president was mounted as a regime change strategy, with opposition parties and some civil society groups becoming a part of it.

The SADC wanted dialogue and a settlement. To this end, the organisation appointed President Mbeki of South Africa as a mediator. The decision to appoint President Mbeki was strategic in that he had a long standing relationship with President Mugabe dating back to the time of Zimbabwe's and South Africa's liberation war. Both men were active members of liberation movements which at independence became ruling parties (ZANU PF in the case of Zimbabwe and ANC in the case of South Africa).

Another similarity is that the personality of President Mbeki is compatible to that of President Mugabe in the context that both men are passionate on the importance of an African identity and the right to self determination, free from external pressures and interferences. In the case of President Mbeki for example, this personality trait can be seen when Jere (2012:12), quotes President Mbeki who in a letter to the G8 in November 2003, wrote, "as Africans, like 
any other people in the world, we have the capacity to determine what is in our best interest, the determination to promote this interest to the best of our ability, and the resolve to honestly confront any tendency that is inimical to the advancement of these interests." In his speech titled I Am an African, Mbeki asserts his connection to the African continent and the experiences of the continent which in turn are his own experiences. He expresses affirmation of an African identity in which he is proud of and to this end expresses, "Today it feels good to be an African." Mbeki's call for an African Renaissance all epitomize what Jere $(2012: 11)$ refers to as "Africa's duty to exercise her right to self determination, free from foreign interference and neo-colonial dependence...the right of the people of Africa to control their natural and other resources and utilise these to achieve their development, for the eradication of poverty and underdevelopment." In essence and in effect, Mbeki has sought to build and consolidate upon the independence of Africans, which was obtained by various liberation movements across the continent.

Similarly, President Mugabe's personality and ideology follow a similar path. For example, as the chief articulator of the country's foreign policy, he has consistently asserted Zimbabwe's policy of non-interference and right to self determination. Perhaps his most notable articulation of this was his vitriolic attack on the British government in front of world leaders at the World Summit on Sustainable Development in Johannesburg in 2002. Mugabe himself instigated, to thundering applause, the most memorable attack on Blair at that gathering "We are not Europeans. We have not asked for an inch of Europe, any square inch of that territory. So Blair, keep your England and let me keep my Zimbabwe." Philminster and Raftopoulos (2005:18) are of the view that "for SADC countries, the powerful anti-imperial message conveyed by Mugabe evoked the regional solidarity campaigns of the recent past." President Mugabe is therefore a reminder of the objectives of the SADC which fundamentally are in favour of self determination, sovereignty and territorial integrity. Therefore the decision to appoint President Mbeki as mediator in Zimbabwe was strategic in that he was a personality who could identify with President Mugabe.

In relation to the SADC led mediation in Zimbabwe, Chikane (2012:77) states that no other outcome apart from regime change was acceptable to the United Kingdom and the United States of America. According to Chikane (2012:77-78):

All forms of covert operations and propaganda focusing on various actors including the SADC, President Mbeki, the governments of the SADC region, and members of the SADC facilitation. The negotiation processes were closely monitored, both overtly and covertly. This included cyberspace operations to monitor all communication between the parties in the negotiations and related players. Moles were placed in some of the delegations to monitor the negotiation process from inside, and diplomats hovered around the negotiating venues or around specific delegations. The SADC summit in Lusaka in 2007 was the scene of sophisticated intelligence operations aimed at destabilising the dialogue between the parties in Zimbabwe and the facilitator, and to influence the SADC leadership to adopt the 'regime change' approach.

However, despite these pressures, President Mbeki remained committed to the SADC mandate. Chikane, (2012:78), states that SADC "leaders were generally opposed to the 
foreign and undemocratic concept of regime change that was reminiscent of what major Western countries did in some of the Eastern European countries following the collapse of the Soviet Union." In some cases therefore, the SADC region is faced with the challenge of implementing its decisions amidst the interference of external actors who have their own agendas.

Another strategic appointment in terms of mediation by the SADC was the appointment of former President of Mozambique, Joaquim Chissano to mediate in the 2009 Madagascar crisis. A diplomat through his appointment as foreign minister under President Samora Machel, President Chissano sought to negotiate a consensual solution to the situation in Madagascar. His ability to bring the Mozambique Civil War to an end in 1992 by negotiating a peace treaty mediated by President Mugabe further made him the appropriate candidate for the SADC to appoint him as a mediator as he was experienced in intrastate conflicts. In addition, he was awarded the Mo Ibrahim prize for Achievement in African Leadership in 2007. This was in recognition of bringing peace, stability and reconciliation to Mozambique. The SADC therefore seeks the best possible personality to address a specific crisis and who will be acceptable by all stakeholders concerned.

\section{Integration Priorities}

While it is a positive development to have South Africa as a member of the SADC, the manner in which the country has attempted to integrate its economy into the world economy has sometimes been at the expense of the SADC. Saurombe (2010:128) states that "to a greater extent South Africa needs to further integrate its economy into the world economy." This has at times resulted in conflict of interests between the SADC and South Africa. This assertion provides an insight into considerations which the SADC member states take when making decisions.

Member states make decisions on SADC integration based on their national priorities. Saurombe (2010:129) gives the example of the European Union and South Africa Trade, Development and Cooperation Agreement (EU/SA TDCA) of 2006. Without focusing too much on the content of the agreement, the author wishes to highlight Saurombe's assertion that the agreement "shows that South Africa has divided attention, with more focus on its trade with the EU than SADC. It also shows that South Africa's economic interests extend far beyond the region (SADC), the continent and ultimately the globe."

Saurombe further asserts that "some SADC member states complained that South Africa only became serious about completing the negotiation for the SADC FTA when it had completed negotiations with the EU." The SADC has expressed concern of the fear of EU goods flooding the regional market. Once EU goods have entered the South African market, controlling their movement into SADC is difficult and there is a risk of undermining agricultural and industrial sectors of the SADC member states. In addition, other developed countries such as the United States of America are seeking to take advantage of opportunities in accessing the African markets through South Africa.

The perceptions of South Africa cannot be faulted as they reflect a realist approach for the advancement of the state. They are also reflective of factors that shape other member states approaches to SADC integration. Decisions by SADC members, which affect their approach 
to decision making in the SADC are influenced by the question of to what extent do available options serve the national interest and the priority they place on issues. To this end, decision making in SADC is affected by a realist mentality rather than an idealist mentality which puts the interests of the collective SADC over the interests of individual states.

For South Africa, and for all SADC member states, the foreign policy imperative revolves around how to mix a state's economic interests (as well as other national interests) with the positions taken by the SADC. The above example on trade shows that South Africa's foreign policy and desire for transition onto the global platform has seen it make decisions which are at times are not compatible with the SADC. For example, South Africa, like many other SADC countries, has called for the reform of the United Nations Security Council (UNSC) and is advocating for a seat as a permanent member. When South Africa voted in favour of UN Resolution 1973, which effected a no-fly zone over Libya, it can be argued that it was towing the line of other UNSC permanent members in a bid to gain their confidence in South Africa as a possible candidate for a permanent seat in the UNSC. In this instance, South Africa's desire to ascend to the international arena was in contrast to the SADC position of African solutions to African problems and respect of Libya's sovereignty. Decision making in the SADC is therefore affected by compromise when balancing regional and state interests.

\section{Conclusion}

If the SADC is to be an effective security community, it is to promote the spirit and the letter of the SADC Treaty. While the characteristics of a security community as given by Adler and Deutsch may only seem like ideals, it is essential to strive for their attainment. The organisation's objectives cannot be attained through individual efforts but requires a collective approach accompanied by a sense of commitment and common purpose. It is very possible that external actors can leverage on disunity in the organisation for state interests which are not consistent with the SADC agenda. The SADC therefore not only needs to speak with one voice but to walk the talk. In their decision making, the SADC member states need to be cognisant of their regional obligations and place priority to them. There is need for the SADC to gain considerable financial freedom to avoid the manipulation of funders in the organisations activities.

\section{References}

Adler, E., \& Barnett, M. (1998). Framework for the Study of Security Communities. In E. Adler \& M. Barnett (Eds.), Security Communities (pp. 30-35). Cambridge: Polity Press. http://dx.doi.org/10.1017/CBO9780511598661

Burgess, S. F. (2008). US Africa Command, Changing security dynamics, and perceptions of US Africa policy.

Chikane, F. (2012). Eight Days in September. The Removal of Thabo Mbeki. South Africa: Picador Africa.

Gray, J. (2013). Can Foreign Aid Buy Cooperation? External Funding and International Organizational Adaptation.

Jere. (2012). The Hurdles and the Triumphs. Retrieved March 17, 2014 from http://newafricanmagazine.com/the-hurdles-and-the-triumphs

Kfir, D. (2014). Challenge that is AFRICOM. Retrieved March 9, 2014, from 
www.idc.ac.i1/publications

Lekota. (2007). Africom should stay off the continent. Retrieved March 7, 2014, from http://www.mg.co.za

Malebang, G. (2012). Peace and Security in Southern Africa: The Case of the SADC. Journal of Human Security Studies, 1.

Matos, O. External shocks and policy responses in the Southern African Development Community Countries. Retrieved March 12, 2014, from http://www.bna.ao/uploads/\%7Bf48e141b-2d01-43f3-b79a-6d3e0815b87f\%7D.pdf

Nathan, L. (2012). Community of Insecurity. Farnham: Ashgate.

Ncube, X. (2014). 'Donors Dictating to SADC'. Retrieved January 18, 2015, from http://www.thezimmail.co.zw/2014/03/27/donors-dictating-to-sadc/

New Zimbabwe. (2011.) Botswana invited troops over Zimbabwe attack fears. Retrieved April 28, 2015, from http://www.newzimbabwe.com/news-5999-Botswana+invited+American+troops /news.aspx Ngoma, N. (2014). Regional Security Structures: Pre and Post Apartheid. Institute of Security Studies. Retrieved January 4, 2014, from www.issafrica.org

Philminster, I., \& Raftopoulos, B. (2005). Mugabe, Mbeki and the Politics of AntiImperialism. Review of African Political Economy, 55.

Regional Integration Key - SADC Leaders. (2011, August 18 August). The Herald, p. 3.

Saurombe, A. (2010). The role of South Africa in SADC regional integration: the making or braking of the organization. Journal of International Commercial Law and Technology, 5(3). 124-131.

The Southern Times. (2012). SADC should put its money where its money is. Retrieved from http://www.southerntimesafrica.com/newsarticle.php?id=7429\&title=SADC\%20put $\% 20$ its $\% 20$ money $\% 20$ where $\% 20$ its $\% 20$ mouth $\% 20$ is\&type $=83 \#$.VO7xri5GR2A

Tjonneland, N. (2006). SADC and donors ideals and practices: From Gaborone to Paris and back. Botswana Institute for Development Policy Analysis.

\section{Copyright Disclaimer}

Copyright reserved by the author(s).

This article is an open-access article distributed under the terms and conditions of the Creative Commons Attribution license (http://creativecommons.org/licenses/by/3.0/). 